\title{
INVOLVEMENT OF RURAL WOMEN IN MANAGING ON-FARM SUSTAINABLE DAIRY PRACTICES IN DISTRICT OKARA
}

\author{
Rabia Mahmood \\ Visiting Lecturer, Government Graduate College Samanabad, Faisalabad, \\ Izhar Ahmed Khan \\ Associate Professor, Department of Rural Sociology, \\ University of Agriculture, Faisalabad \\ Sadaf Mahmood \\ Assistant Professor, Department of Sociology, \\ Government College University Faisalabad \\ sadaf.mahmood@gcuf.edu.pk
}

\begin{abstract}
In Pakistan, livestock is playing a considerable role in the country's economy, agricultural development and fulfilling the domestic dairy needs of households. We cannot negate the prominence of females' participation in this sector. This study is organized to identify the involvement of rural women in managing dairy farm practices. Data was collected from 120 rural women who were participating in dairy farm activities in District Okara through purposive sampling technique with the help of a well-structured interview schedule. The results showed that mostly young women in the age group of 19 to 38 were involved in dairy farm practices. $60.0 \%$ of the respondents were illiterate and almost $65.0 \%$ family's occupation was agriculture. $32.5 \%$ respondents were involved in dairy farm practice from 6 to 10 years while half of the respondents were spending their 8 to 10 hours in these activities. Their involvement in on-farm activities was unpaid and considered as their domestic duty. Mostly, they were involved in managing on-farm sustainable dairy practices that includes; fodder cutting, watering, cleaning Chad and taking care of animals. Their participation and management of on-farm activities should be documented and acknowledged. The government should focus on female's education and paid participation in agricultural activities.

Keywords: Women participation, On-farm livestock management practices, District Okara, Punjab, Pakistan
\end{abstract}

\section{INTRODUCTION}

Agriculture is backbone of our country's economy and sharing 19.3\% of GDP of the country although this shares decreases in these years (Economic Survey of Pakistan, 2019-20). In our neighbouring countries like India and Bangladesh, the researchers have found that women's participation in agricultural activities is higher than that of men (Upadhyay \& Desai, 2011; Prakash, 2003; Tacio, 2003). Females play an important role in on-farm dairy activities as sale of milk, fodder management, and take care of animals but they are less involved in off-farm activities like: contact with offices, progressive farmers and banks (Jadav, 2014, Upadhyay \& Desai, 2011). Women, children and small animals have strong relationship which shows the care of women towards animals. Rural women strongly participate in livestock activities in Punjab and in other provinces of Pakistan, like other world (Luqman, 2013).

In Pakistan, women are working as housewives and engaged in domestic responsibilities. Additionally, the rural women are contribution in agriculture including the cultivation of crops, and livestock management which is the major concern of our research. Women are spending 10 to 12 hours in work daily in which 4 to 5 hours in household and 6 to 7 hours in livestock management activities. The men worked 20 to 30 per cent less than the females (Shafiq 2008). Livestock is an integral part of agriculture and this sector is fulfilling the domestic demand of the country. The contribution of livestock remains $58.55 \%$ in agriculture value addition. Despite all these important facts, the role of women in livestock sector is unrecognizable until now. They are 
helping in taking care of livestock including; to take them for grazing, look after them, to make dairy products and in the sale of milk and prepared dairy products in addition to their household duties. Rural women are significantly contributing in income generating activities of the family through their participation in the livestock sector in which their contribution always remained silent and ignored. Rural women face a lot of problems in livestock sector as insufficient technology demonstration, credit facility, and proper information about the care of animal. Lack of training, improper treatment, care and awareness cause the diseases. Women pay much more time in dairy farming but their decision power is very poor (Riasat, 2014). Besides this, they are also participating in agricultural activities like, sewing and cultivation of crops. They are working till dawn to dusk but their contribution is underprivileged. This hard work is not making them empowered and not recognizing their contribution towards their family income and for the development of the country as well. Many researchers endorsed that the role of women in decision making is essential for the rapid economic development of the country (Chayal et al., 2013). In developed countries women are participating as agricultural labour force $36.7 \%$ but in developing countries ratio increased to $43.6 \%$. Female participation is more than male in livestock and agricultural activities (Tipilda, 2008). Livestock is not only a source of milk and meat but also provide wool, hairs, skin and bones as a raw material to fulfil other human needs. Milk, egg, meat and other dairy product are used for other production (Macleod and Wilsomore, 2002). There is a dire need to study the challenges of the women who participated in livestock production and management as they are contributing a significant share in agriculture development and uplifting the country's economy.

\section{OBJECTIVES}

Keeping in view the situation that Pakistani women are contributing in on-farm dairy activities as well as fulfilling their domestic responsibilities without any recognition and monetary reward, the present study aims to monitor the following objectives:

- To look into the personal and demographic information of the respondents

- To investigate their participation in the on-farm livestock management activities

- To suggest some recommendation based on our research to enhance the situation of women

\section{REVIEW OF LITERATURE}

Livestock is an integral part of agriculture and this sector is fulfilling the domestic demand of the country. The contribution of livestock remains $58.55 \%$ in agriculture value addition. Livestock can increase the economic condition and living standard of landless poor. It is a hope for poor. A huge population of livestock including Buffalos (Second largest population of buffalos in Pakistan out of the whole world), Cows, Sheep, horses, goat etc. in favourable environment and unique geographical location. Animals are used for rural transportation, fodder chopping, ploughing, and water uplifting and also for land levelling. Despite all these important facts, the role of women in livestock sector is unrecognizable until now. Chayal et al. (2013) stated that they were helping in taking care of livestock including; to take them for grazing, look after them, to make dairy products and in the sale of milk and prepared dairy products. In addition to their domestic obligations, they were considerably participating in income generating activities of the family through their participation in the livestock sector in which their contribution always remained silent and ignored. This hard work was not making them empowered and not recognizing their contribution towards their family income and for the development of the country as well. Jadav (2014) studies that the involvement of female in decision making regarding dairy farm was very low because of their less contact with offices, progressive farmers and banks (Jadav 2014, Upadhyay, 2011).

Agriculture plays an important role in rural development. Several studies in Pakistan found that women were investing 9 to 12 hours in livestock management activities in Punjab, Pakistan. They were mostly illiterate and engaged in several kinds of livestock management activities (Jabeen, 2014; Manzoor, 2014; Batool, 2014; Rani, 2015; Wahab, 2016). Another research stated that women, children and small animals have strong relationship which shows the care of women towards animals. Rural women strongly participate in livestock activities in Punjab and in other provinces of Pakistan, like other world (Luqman, 2013). Women were participation in dairy farming practices and the results of the multiple linear regression showed that women were getting empowered through small-scale 
dairy farming activities (Yasmin \& Ikemoto, 2015). In India, rural farm women have control over non-financial activities like construction of shed, take care of animals, milking and so many other works but they did not have any control over financial activities like selling and purchasing of animals etc. (Kavithaa \& Rajkumar, 2016). In another study in India by Patel (2016), it was found that mostly livestock production was handled by women. They were performing livestock care activities including shed cleaning; fodder collection, feeding, watering, milking, health care, value addition, householdlevel processing as well as few of them were performing marketing activities. Still, the gender inequalities were exit in Indian villages.

Yisehak (2008) found that women did not acquire opportunities and resources in agriculture and livestock as equal to men such as agricultural land, input access due to culture, social and traditional dynamics. There has been big gap between resources, land and population. Women performed more duties than males as farming promotion, fragile animal management (sick, pregnant and injured animals), activities relating to dairy (Butter, cheese and milk production), barn cleaning and sale milk and milk products in Nigerian. Meat and animals were selling by male members. Selling activities were performed by male but in field activities and livestock activities duties are perform mostly by females. Milk processing is done by female lonely.

WHO (2019) stated that the main problem was unequal rights of women because of patriarchal thinking and gender based bias. It was proposed that to increase the women capacity building, we should give them the right of independence. Rural women play many roles as agricultural labour, managing water and fuel, cooking, maintaining and cleaning house, take care of senior household members, young and children and participate in managing all livestock activities. They are working early in the morning to late night at home, field, livestock and assist their husbands too. They spend fifteen hours in a day in work including 5-6 hours in livestock management. Livestock management is considered the duty of females only. Females perform duties of cleaning shed, cutting fodder, milking, and value addition of milk and also take care of sheep/goats (Arshad 2010, Younas, 2007, Javeed, 2006). Rural women spend 10 to 12 hours in work daily in which 4 to 5 hours in household and 6 to 7 hours in livestock management activities. The men worked 20 to 30 per cent less than the females (Shafiq, 2008).

In developed countries women are participating as agricultural labour force $36.7 \%$ but in developing countries ratio increased to $43.6 \%$. Female participation is more than male in livestock and agricultural activities (Tipilda, 2008). Livestock is not only a source of milk and meat but also provide wool, hairs, skin and bones as a raw material to fulfil other human needs. Milk, egg, meat and other dairy product are used for other production (Macleod and Wilsomore, 2002).

\section{THEORETICAL FRAMEWORK}

The sociological empirical research is incomplete without sound theoretical background. The researcher based on the theory of cultural modernization theory and further, the human development perspective was discussed. Human development is core component of modernization and subdivided into three sections; economic, ethical, and institutional. The focus was the individual choice (Welzel, Inglehart, \& Klingemann, 2001). All the three components are related to this study. The economic component includes the autonomy resources and resource allocation is its underlying process which is the major concern here. Ethical component considers liberty ambitions that focus on cultural modernization and the freedom in opportunities is the part of institutional component. The human development perspective presents the order of social modernization that contributes in the rise to a culture where the autonomy of human and their choice are extremely valued (Welzel, Inglehart \& Klingemann 2003; Inglehart \& Welzel 2005). According to Welzel (2003), intensifications in human resources decrease limitations on human self-sufficiency and personal choice in everyday lives of individuals'. This permits people to give more weightage to self-expression like: tolerance, personal choice in child-rearing strategies, and self-fulfilment. This was the reason which increases empowerment among women throughout society (Inglehart \& Norris 2003; Inglehart \& Welzel 2005). 
Few from these theories describe the procedures that have a greater association between economic resources to increasingly emancipative values, like gender equality. For example, in 1997, Inglehart has linked the social modernization and democratization which includes the new values regarding quality-of-life, as women's empowerment (Inglehart, 1997). In more favourable contemporary societies where women empowerment was appreciated, more gender equality was honoured with the connection to cultural modernity which increased the societal women's empowerment. They suggested that women should be empowered and participate in decision making and their performance in agriculture production was affected by their domestic responsibilities (Rasheed et. al., 2020; Liu et al., 2019; Peng \& Wen, 2016).

\section{MATERIAL AND METHODS}

The study was conducted in the rural areas of district Okara, Punjab, Pakistan. Punjab is divided into 36 districts and Okara is one of them and very famous for its livestock activities that's why the researcher was interested to conduct her study there. Okara is subdivided in three Tehsils/ towns (Okara, Renala Khud \& Depalpur). One tehsil Okara was selected through simple random sampling technique and tehsil Okara was subdivided into 41 union councils. 6 union councils from $41 \mathrm{UCs}$ and 2 villages from each union council were selected randomly. 10 female respondents who were participating in agriculture activities were selected from each village to fulfil the need of 120 respondents through purposive sampling technique. In total, 120 rural women were interviewed who were participating in on-farm livestock activities. At the first stage, district Okara was selected through purposive sampling technique. At the second stage, thesil Okara were selected out of three tehsils/towns (Okara, Renala Khurd, Depalpur) through simple random sampling technique. Afterwards, six union councils were selected randomly named: 45/GD, 34/GD, 24/GD, 12/GD, 18GD and $2 / 4 \mathrm{~L}$ at third stage of sample selection. At the fourth stage, two villages from each union council were selected randomly named: 45/GD, 43/GD, 34/GD, 33/GD, 24/GD, 23/GD, 12/GD, 11/GD, 18/GD, 17/GD, 2/4L and 3/4L. 10 females were selected from each village to achieve the sample of 120 respondents. A well-structured interview schedule was design for conducting interview from the respondents which consist of close-ended and open-ended questions. The demographic information and questions regarding their on-farm activities and regarding their assessment to empowerment were the part of questionnaire. The descriptive and inferential statistics was applied with the help of SPSS. The frequency and percentages were calculated to understand the general situation of women. The cross tabulation was done to check the relationship of the variables.

\section{RESULTS AND DISCUSSION}

The results of the study have been divided into sub-section. In the first section, the research discusses the demographic information of the respondents while in the second section, their on-farm activities are discussed. Third section highlights their problems.

Table 1 shows that $15 \%$ respondents were in the age group of 18 or less than 18 years old who were involved in dairy farm practices and $22.5 \%$ of the respondents were between the age group of 19-28 years old. Majority of respondents $30 \%$ belong to the age of 29 to 38 years old. $21.7 \%$ of the respondents were performing the dairy farm activities in the age group of 39 to 48 years old. Almost $11 \%$ of the respondents were above 48 years old. The mean age of the respondents was 2.96 with the standard deviation of 1.318. It is concluded from the above results that the majority of the females were between the age of 19 to 48 years old which shows that young and healthy women were involved in on-farm activities. 
Table 1: Distribution of respondent according to their background information

\begin{tabular}{llcc} 
Variable & Categories & Frequency & Percentage \\
\hline \hline Age* & $\leq 18$ & 18 & 15.0 \\
& $19-28$ & 27 & 22.5 \\
& $29-38$ & 36 & 30.0 \\
& $39-48$ & 26 & 21.7 \\
& $49-58$ & 07 & 5.8 \\
Education* & $\geq 59$ & 06 & 5.0 \\
& Illiterate & 72 & 60.0 \\
& Primary & 38 & 31.7 \\
Marital & Middle & 08 & 6.7 \\
Status & Higher & 02 & 1.7 \\
& Unmarried & 33 & 27.5 \\
& Married & 82 & 68.3 \\
\hline \hline
\end{tabular}

*Mean \& Standard Deviation of Age $(\mathrm{M}=2.96, \mathrm{SD}=1.318)$

*Mean \& Standard Deviation of Education $(\mathrm{M}=1.50, \mathrm{SD}=.698)$

Riasat (2014) conducted his research on the topic of "rural development through women participation in livestock care and management in district Faisalabad" Pakistan and found a bit different categories of age of the females who were contributing in livestock activities. In the present study in 29 to 38 years of age female mostly done livestock management activities but in the 2014 study 41 to 50 year of age females mostly do dairy farm practices. Presented of table 1 shows that $60 \%$ of females are illiterate and $31.7 \%$ respondents are primary passed. Middle passed by $6.7 \%$ in this study and very small part of respondent $1.7 \%$ are matric pass involved in dairy farming. The mean of caste of respondent is 1.50 and .698 standard deviation. Similarly, Riasat (2014) found that majority of respondents were illiterate. A major part of respondents $68.3 \%$ are married show in the table 1 . Unmarried females are $27.5 \%$, widow are $3.3 \%$ and $.8 \%$ divorced female participate in livestock management. The mean of marital status of respondent is 1.78and .542 standard deviation. Kathiriya, et al., (2013) found the similar results Rajkot district in which majority or the respondents were married.

Table 2: Distribution of respondent according to year involved in dairy farm practices And working hours of respondent (daily)

\begin{tabular}{lllllr} 
Variable & Categories & Frequency & Percentage & Mean & $\begin{array}{c}\text { Standard } \\
\text { Deviation }\end{array}$ \\
\hline \hline Years & $\leq 5$ & 32 & 26.7 & 2.45 & 1.276 \\
& $6-10$ & 39 & 32.5 & & \\
& $11-15$ & 25 & 20.8 & & \\
& $16-20$ & 11 & 9.2 & & \\
Hours & $\geq 20$ & 13 & 10.8 & 2.18 & .917 \\
& $\leq 7$ & 26 & 21.7 & & \\
& $8-10$ & 61 & 50.8 & & \\
& $11-13$ & 18 & 15.0 & & \\
\hline
\end{tabular}

Table 2 shows that $26.7 \%$ of the respondents were engaged in dairy farm activities since 5 years of less, $32.5 \%$ were serving from 6 to 10 years in livestock management. 20.8\% stated that they were engaged since 11 to 15 years and $9.2 \%$ respondents involved in dairy farming since 16 to 20 years and $10.8 \%$ females engaged in livestock activities 20 or more than 20 years. The mean of year's involvement in dairy practices was 2.45 with the standard deviation of 1.276 . On average, 50\% women were spending 8 to 10 hours in livestock activities with the mean of 2.18 and standard 
deviation of 0.917. Ishaq (2016) found the similar results with $56.52 \%$ respondents were spending 8 to 10 hours.

Table 3: Distribution of respondent according to role in livestock management

\begin{tabular}{|c|c|c|c|c|c|}
\hline Indicator & $\begin{array}{c}\text { Frequently } \\
\text { F (\%) }\end{array}$ & $\begin{array}{c}\text { Sometimes } \\
F(\%)\end{array}$ & $\begin{array}{l}\text { Never } \\
\text { F (\%) }\end{array}$ & Mean & SD \\
\hline \multicolumn{6}{|c|}{ Levels } \\
\hline Cultivation of fodder & $40.0(40.0)$ & $441(34.2)$ & $31(25.8)$ & 1.86 & .802 \\
\hline Poultry raising & $70(58.3)$ & $28(23.3)$ & $22(18.3)$ & 1.60 & .782 \\
\hline Raising animals & $99(82.5)$ & $16(13.3)$ & $05(4.2)$ & 1.22 & .505 \\
\hline Washing animals & $83(69.2)$ & $34(28.3)$ & $03(2.5)$ & 1.33 & .524 \\
\hline Shed cleaning & $43(35.8)$ & $40(33.3)$ & $37(30.8)$ & 1.95 & .818 \\
\hline Making Dunk cake & $72(60.0)$ & $34(28.3)$ & $14(11.7)$ & 1.52 & .698 \\
\hline Watering animals & $97(80.8)$ & $12(10.0)$ & $11(9.2)$ & 1.28 & .624 \\
\hline Sale \& purchase animals & $12(10.0)$ & $24(20.0)$ & $84(70.0)$ & 2.60 & .666 \\
\hline Milking & $73(60.8)$ & $38(31.7)$ & $9(7.5)$ & 1.67 & .634 \\
\hline Yogurt preparation & $74(61.7)$ & $26(21.7)$ & $20(16.7)$ & 1.55 & .765 \\
\hline Collection of eggs & $63(52.2)$ & $31(25.8)$ & $26(21.7)$ & 1.69 & .807 \\
\hline Selling dairy product & $43(35.8)$ & $39(32.5)$ & $38(31.7)$ & 1.97 & .840 \\
\hline
\end{tabular}

Table 3 represents that fodder cultivate by majority of respondents $40 \%$ frequently and sometime cultivate fodder by $34.2 \%$. Respondents $25.8 \%$ never cultivate fodder in their life with the (mean $=1.86, \mathrm{SD}=.802)$. Wajiha $(2016)$ conducted her research in the rural areas of Lahore found similar results. The data presents in table 3 show that poultry raised by $58.3 \%$ females, $23.3 \%$ respondents take care poultry sometime and $18.3 \%$ females don't do this practice with the (Mean $=$ $1.60, \mathrm{SD}=.782)$. Shafiq $(2008)$ found in Balochistan that women $(90 \%)$ were more involved in poultry care women including girls.

Table 3 shows that frequently $82.5 \%$ take care of animal, $13.3 \%$ manage livestock activities sometime and respondent never do this duties $4.2 \%$ with the (mean $=1.22$ and $\mathrm{SD}=.505) .69 .2 \%$ respondents frequently washing, cleaning animals and their shelter and $28.3 \%$ do this duty sometime and $2.5 \%$ respondents never do this. The mean washing animal is 1.33 and .524 standard deviations. Arshad (2013) found similar results. 35.8\% females frequently building and cleaning animal shed.33.3\% female this task done sometime and 30.8\% never do this with the (mean $=1.95$ and $\mathrm{SD}=$ .818). Mulugeta (2014) found different results in Ethiopia like almost $99 \%$ of women were engaged in cleaning of animal shed.

The making and collecting dunk cake frequently was $60 \%$ respondents, $28.3 \%$ and $11.7 \%$ remained in sometimes and never respectively. The mean of making and collecting dunk cake (mean is 1.52 and SD is .698). In a study in rural areas of Lahore by Ishaq (2016) presented almost parallel results.

Our data show that watering animals task was mostly done by females that is $80.8 \%$ and $10 \%$ females watered animals sometime and 9.2\% don't do this duty (mean $=1.28$ and SD $=.624$ ). Mulugeta (2014) found different results in Ethiopia. Interestingly, respondent's participation in sale and purchase of animals remained minimal with $10 \%$ which shows that women were not the part of decisions with the mean of 2.60 and .666 standard deviations. Similar results were found by Mulugeta (2014) which shows that women empowerment indicators in livestock shows more or less similar results in the developing countries.

Mostly females $60.8 \%$ frequently milking the animals with the mean of milking of animal is $(1.67, \mathrm{SD}=.634)$. The mean of churning and yogurt preparation is 1.55 and .765 standard deviation. Females frequently collect eggs $(52.2 \%)$ with the mean 1.69 and .807 standard deviation. In the Mulugeta study $84.4 \%$ respondent collecting eggs regularly. 
The selling of dairy products.35.8\% respondents sell dairy product frequently, sometime dairy products sell by $32.5 \%$ and $31.7 \%$ respondents never sell dairy products. The mean of selling of dairy product is 1.97 and .804 standard deviation.

\section{CONCLUSION AND RECOMMENDATIONS}

It is the fact that women of rural areas work from dawn to dusk in house, field and in dairy farming but their work is unrecognizable. Agriculture share 19.3\% GDP of the country. The contribution of livestock remains $58.55 \%$ in agriculture value addition. In our neighbouring countries like India and Bangladesh, the researchers have found that women's participation in agricultural activities is higher than that of men. Similar results were found in our study that $50 \%$ of the women were spending 8-10 hours in livestock activities but their contribution is unrecognized. Females play an important role in on-farm dairy activities as sale of milk, fodder management, and take care of animals but their participation in off-farm activities and in economic activities as purchase and sale of animals, taking loans and choose animal for dairy is very low.

Their on-farm production can be enhanced with the help of agriculture extension officers. The government should develop agriculture extension offices so they can get proper guidance for the take care of their animals. Especially, female extension workers should be hiring in these centres so the females feel comfortable to visit and consult with them. They have to access to micro credits to improve the extent of their practices. Above all, the family and society should acknowledge their unpaid or underpaid efforts for livestock management which is significantly contributing in our country's development. The family should support and privilege the efforts of the women and help them to increase their livestock activities. Proper medical facilities should be providing for animal health for the development of livestock sector. The women participation should have encouraged and must be acknowledged and paid as well. The payment can be the monetary benefits as well as power of decision making with the recognition of their work.

\section{REFERENCES}

Arshad, S., Muhammad, S., \& Ashraf, I. (2013). Women's participation in livestock farming activities. The journal of animal \& plant sciences, 23(1), 304-308.

Arshad, S., Muhammad, S., Randhawa, M. A., Ashraf, I., \& Chuadhry, K. M. (2010). Rural women's involvement in decision-making regarding livestock management. Pakistan Journal of Agricultural Sciences, 47(2), 1-4.

Batool, Z., Warriach, H. M., Ishaq, M., Latif, S., Rashid, M. A., Bhatti, A., ... \& Wynn, P. C. (2014). Participation of women in dairy farm practices under smallholder production system in Punjab, Pakistan. The Journal of Animal and Plant Sciences, 24(4), 1263-1265.

Chayal, K., Dhaka, B. L., Poonia, M. K., Tyagi, S. V. S., \& Verma, S. R. (2013). Involvement of farm women in decision-making in agriculture. Studies on Home and Community Science, 7(1), 3537.

Førsund, F. R., Lovell, C. K., \& Schmidt, P. (1980). A survey of frontier production functions and of their relationship to efficiency measurement. Journal of econometrics, 13(1), 5-25.

GoP, 2020. Economic Survey of Pakistan, 2019-20. Finance Division. Ministry of Finance, Government of Pakistan. Islamabad.

Ishaq, W., \& Memon, S. Q. (2016). Roles of women in agriculture: A case study of rural Lahore, Pakistan. Journal of rural development and agriculture, 1(1), 1-11.

Inglehart, R. (1997). Modernization and postmodernization in 43 societies (pp. 67-107). Princeton university press.

Jabeen, N. 2014. A study of Women participation in livestock care and management in district Jhang. Unpublished M.Phil. Thesis, Department of Rural Sociology, University of Agriculture Faisalabad.

Jadav, S. J., Rani, V. D., Mudgal, S., \& Dhamsaniya, H. B. (2014). Women empowerment through training in dairy farming. Asian Journal of Dairy and Food Research, 33(2), 147-153.

Javed, A., Sadaf, S., \& Luqman, M. (2006). Rural women's participation in crop and livestock production activities in Faisalabad, Pakistan. Journal of Agriculture and Social Sciences (Pakistan). 
Kathiriya, J. B., Damasia, D. M., \& Kabaria, B. B. (2013). Role of rural women in dairy farming of Rajkot district. Tamilnadu Journal of Veterinary and Animal Science, 9(4), 239-247.

Kavithaa, N. V., \& Rajkumar, N. V. (2016). Decision Making Behaviour of Farm Women in Dairy Farming Activities in Erode District of Tamilnadu. International Journal of Science, Environment and Technology, 5(2), 416-419

Luqman, M., Shahbaz, B., Khan, I. A., \& Safdar, U. (2013). Training need assessment of rural women in livestock management-case of Southern Punjab, Pakistan. Journal of Agricultural Research (03681157), 51(1).

Liu, J., Xu, Z., Zheng, Q., Hua, L. (2019). Is the feminization of Iabor harmfuI to agricuIturaI production? The decision-making and production controI perspective. Journal of Integrative Agriculture, 18(6), 1392-1401.

Macleod and Wilsomore (2002). Appendix 11. The Delivery of Animal Health Service to the Poor; A Review in: International Livestock Research Institute, Nairobi, Kenya.

Manzoor, A. 2014. Women participation in livestock management in rural area of district Nankana Sahib. M.Phil. Thesis, Dept. of Rural Sociology, University of Agriculture, Faisalabad.

Mulugeta, M., \& Amsalu, T. (2014). Womens role and their decision making in livestock and household management. Journal of Agricultural Extension and Rural Development, 6(11), 347-353.

Patel, S. J., Patel, M. D., Patel, J. H., Patel, A. S., \& Gelani, R. N. (2016). Role of women gender in livestock sector: A review. Journal of Livestock Science, 7, 92-96.

Prakash, D. (2003). Rural Women, Food Security And Agricultural Cooperatives, Rural Development And Management Centre 'The Saryu', J-102 Kalkaji, New Delhi 110019. India February.

Peng, D., \& Wen, L. (2016). Is the aging and feminization of the rural labor force reducing the efficiency of grain production-Based on the comparative analysis of the south and north of the random frontier. Agricultural Technology and Economy, 2, 32-44.

Rani, A. 2015. Gender empowerment through livestock management in rural area of Tehsil Summandri District Faisalabad. Unpublished M.Phil. Thesis, Department of Rural Sociology, University of Agriculture, Faisalabad, Pakistan.

Riasat, A., Zafar, I, M., Khan, A. I., Amir, M. R., \& Riasat, G., (2014). Rural Development through Women Participation in livestock Activities Care and Management in District Faisalabad. $J$. Glob. Innov. Agric. Soc. Sci., 2014, 2(1): 31-34.

Rasheed, A., Mwalupaso, G. E., Abbas, Q., Tian, X., \& Waseem, R. (2020). Women participation: a productivity strategy in rice production. Sustainability, 12(7), 2870.

Shafiq, M. U. H. A. M. M. A. D. (2008). Analysis of the role of women in livestock production in Balochistan, Pakistan. J Agri Soc Sci, 4, 18-22.

Tacio, H. D. (2003). Women hold key to food production. The Manila Times. May, 27.

Tipilda, A. and K. Panhwar, (2008). Women and livestock development: A review of the literature.ILIR Innovation Works Discussion Paper 01-19.

Upadhyay, S., \& Desai, C. P. (2011). Participation of farm women in animal husbandry in Anand District of Gujarat. Journal of Community Mobilization and Sustainable development, 6(2), 117-121.

Welzel, C., Inglehart, R., \& Klingemann, H. D. (2001). Human development as a general theory of social change: A multi-level and cross-cultural perspective (No. FS III 01-201). WZB Discussion Paper.

Welzel, C., \& Inglehart, R. (2001). Human development and the explosion of democracy: Variations of regime change across 60 societies (No. FS III 01-202). WZB Discussion Paper.

Welzel, C., Inglehart, R., \& Klingemann, H. D. (2003). Human development as a theory of social change: a cross-cultural perspective. Euro J of Pol Sci, 42, 341-379.

Welzel, C., \& Inglehart, R. (2005). Democratization as the growth of freedom: The human development perspective. Japanese Journal of Political Science, 6(03), 313-343.

Wahab, P., Qadeer, A., Shamas, D., \& Arif, M. (2016). Role of Women in Livestock Management in Rural Areas of District Attock, Pakistan. Journal of Innovation Research and Development, 1(1), 20-24.

WHO. 2019.2 Women health: available at: http//whqlibdoc.who.int/publications/2019/9787241563857_eng.pdf. 
Ikemoto, S. Y. Y. (2015). Women's Empowerment through Small-Scale Dairy Farming in Selected Areas of Bangladesh. Asian Social Science, 11(26), 290-301.

Yisehak, K. (2008). Gender responsibility in smallholder mixed crop-livestock production systems of Jimma zone, South West Ethiopia. Livestock Research for Rural Development, 20(11), 12-19.

Younas, M., Gulrez, S., \& Rehman, H. (2007, Dec 17). Women's role in livestock production. The Dawn. 